\title{
Reduction in bacterial load using hypochlorous acid hygiene solution on ocular skin
}

\author{
This article was published in the following Dove Press journal: \\ Clinical Ophthalmology \\ 13 April 2017 \\ Number of times this article has been viewed
}

\author{
David W Stroman' \\ Keri Mintun' \\ Arthur B Epstein ${ }^{2}$ \\ Crystal M Brimer ${ }^{3}$ \\ Chirag R Patel ${ }^{4}$ \\ James D Branch ${ }^{5}$ \\ Kathryn Najafi-Tagol' \\ 'NovaBay Pharmaceuticals, Inc., \\ Emeryville, CA, ${ }^{2}$ Ophthalmic Research \\ Consultants of Arizona, Phoenix, AZ, \\ ${ }^{3}$ Crystal Vision Services, Wilmington, \\ NC, ${ }^{4}$ Turner Eye Institute, San \\ Leandro, CA, ${ }^{5}$ James D. Branch \\ Ophthalmology, Winston Salem, \\ NC, USA
}

Purpose: To examine the magnitude of bacterial load reduction on the surface of the periocular skin 20 minutes after application of a saline hygiene solution containing $0.01 \%$ pure hypochlorous acid $(\mathrm{HOCl})$.

Methods: Microbiological specimens were collected immediately prior to applying the hygiene solution and again 20 minutes later. Total microbial colonies were counted and each unique colony morphology was processed to identify the bacterial species and to determine the susceptibility profile to 15 selected antibiotics.

Results: Specimens were analyzed from the skin samples of 71 eyes from 36 patients. Prior to treatment, 194 unique bacterial isolates belonging to 33 different species were recovered. Twenty minutes after treatment, 138 unique bacterial isolates belonging to 26 different species were identified. Staphylococci accounted for $61 \%$ of all strains recovered and Staphylococcus epidermidis strains comprised $60 \%$ of the staphylococcal strains. No substantial differences in the distribution of Gram-positive, Gram-negative, or anaerobic species were noted before and after treatment. The quantitative data demonstrated a $>99 \%$ reduction in the staphylococcal load on the surface of the skin 20 minutes following application of the hygiene solution. The total S. epidermidis colony-forming units were reduced by $99.5 \%$. The $\mathrm{HOCl}$ hygiene solution removed staphylococcal isolates that were resistant to multiple antibiotics equally well as those isolates that were susceptible to antibiotics.

Conclusion: The application of a saline hygiene solution preserved with pure $\mathrm{HOCl}$ acid reduced the bacterial load significantly without altering the diversity of bacterial species remaining on the skin under the lower eyelid.

Keywords: blepharitis, microbiome, Propionibacterium acnes, Corynebacterium, Staphylococcus aureus, Staphylococcus epidermidis

\section{Introduction}

The skin is an ecosystem of diverse habitats and niches that support a wide array of microorganisms, including bacteria, fungi, and viruses. ${ }^{1}$ Many of these species are harmless or even beneficial, providing protection against more pathogenic species. Early studies identified bacteria in the periocular region. Dougherty and $\mathrm{McCulley}^{2}$ reported that Staphylococcus aureus, coagulase-negative Staphylococcus spp., Propionibacterium acnes, and coryneform bacteria were the most commonly isolated species.

Blepharitis, which can be subdivided into anterior and posterior blepharitis, is a common cause of ocular irritation. ${ }^{3}$ Meibomian gland dysfunction (MGD) is a wellrecognized cause of tear instability and an important contributing factor in dry eye disease. $^{4-7}$ Anterior blepharitis affects the eyelid skin, base of the lashes, and eyelash follicles, while posterior blepharitis affects the posterior lid margin. ${ }^{3}$ If left untreated, blepharitis and MGD can lead to chronic inflammation of the meibomian glands and
Correspondence: David W Stroman NovaBay Pharmaceuticals, Inc., 2000 Powell Street Suite II50, Emeryville, CA 94608, USA

Tel +I 5108998813

Email dstroman@novabay.com 
vascular changes around the eyelid margin. ${ }^{3,8}$ There is a potential for trichiasis with corneal irritation, dry eye, and even damage to the cornea. ${ }^{9}$

Since the skin microbiome contributes to both infection and the prevention of eye diseases, an understanding of the resident microbial community is essential for the prevention and treatment of blepharitis and MGD. ${ }^{10}$ Some microorganisms within the diverse population in the periocular skin may trigger blepharitis symptoms. However, some investigators theorize that some resident bacterial species may play a beneficial role by competing with more pathogenic organisms. ${ }^{11}$

Numerous studies to characterize microorganisms from blepharitis have been conducted. ${ }^{2,12}$ Using culture-based approaches, isolates of $S$. aureus, coagulase-negative Staphylococcus, lipophilic Corynebacterium spp., and $P$. acnes were the predominate bacteria recovered from blepharitis patients. ${ }^{2}$ Groden et al ${ }^{12}$ reported that isolates of Acinetobacter spp., in addition to the Staphylococcus epidermidis, $P$. acnes, Corynebacterium spp., and S. aureus, were the most common of the 57 unique bacterial species recovered from 332 patient lids with blepharitis and 160 control patients without blepharitis. Interestingly, S. epidermidis, P. acnes, and Corynebacterium spp. were isolated in significantly greater quantities on the lids of patients with blepharitis as compared to the control patients.

Suzuki et al ${ }^{13}$ reported that when heat-killed $P$. acnes were injected into the rat corneal stroma, a cell infiltration pattern developed that was similar to a delay hypersensitivity reaction. The authors hypothesized that $P$. acnes could be a causative bacterial species for ocular surface inflammation.

Hypochlorous acid ( $\mathrm{HOCl})$ is a natural antibacterial agent. Pure $\mathrm{HOCl}$ is produced naturally as an element of the human immune response. ${ }^{14}$ During the "oxidative burst", small, highly reactive molecules, such as $\mathrm{HOCl}$, are generated as white blood cells respond to pathogens in the body. ${ }^{15}$ This compound is an oxidant that kills bacteria through protein and lipid peroxidation and/or halogenation. ${ }^{15} \mathrm{HOCl}$ has a broad spectrum of activity and exhibits rapid kill kinetics. ${ }^{16,17}$ The compound $(0.01 \%)$ is the key preservative ingredient in an ocular hygiene product that is designed to clean the area around the lids and lashes. ${ }^{17}$ This study measured the effect of eyelid hygiene solution preserved with $0.01 \% \mathrm{HOCl}$ on ocular skin flora.

\section{Materials and methods}

This multicenter, post-marketing study was conducted across four private practice sites in accordance with the ethical principles originating from the Declaration of Helsinki
(1964, 1975, 1983, 1989, and 1996), the International Conference on Harmonization, and Good Clinical Practice and in compliance with local regulatory requirements. The study was also compliant with the Health Insurance Portability and Accountability Act, where applicable. The study protocol was reviewed and approved by the Quorum Institutional Review Board, Seattle, WA. Prospective patients were screened and those who satisfied the inclusion/exclusion criteria were enrolled into the study. Participants signed an institutional review board-approved informed consent forms prior to enrollment. The study was registered on the ClinicalTrials.gov website (NCT02455895).

\section{Key inclusion criteria}

Participants in the study were males or females of any race and at least 6 years of age. Eligibility criteria for a recommendation to use eyelid cleansing/scrubs included signs of acute or chronic blepharitis, such as eye lid debris (sleeves, collorates, flakes, crusting) requiring eye lid cleansing/scrubs, and/or signs consistent with mild, moderate, or severe MGD such as dilated and blocked glands with inspissated secretions sluggish or stagnant upon expression. Participants agreed to remove contact lenses, if applicable, before the application until after the post 20 minutes specimens were collected.

\section{Key exclusion criteria}

Participants were excluded for any of the following reasons: the presence of signs and symptoms of bacterial or allergic conjunctivitis or allergic dermatitis at the day 1 study visit; blepharitis induced by the use of preserved or unpreserved glaucoma medications; suspected fungal, viral, Chlamydia, or Acanthamoeba infection based on clinical diagnosis; visual acuity not correctable to $1.0 \mathrm{Log}$ MAR or better (equivalent to Snellen 20/200) in either eye using either a Snellen or ETDRS chart; use of any preserved or non-preserved glaucoma medications during the 14 days prior to the study; presence of nasolacrimal duct obstruction or a punctal plug in either eye; any systemic or ocular disease or disorder, complicating factors or structural abnormality that would negatively affect the conduct of the study; presence of active inflammation and/or active structural change in the cornea, iris, or anterior chamber; and any current immunosuppressive disorder (eg, HIV positive) or use of immunosuppressive therapy (including chemotherapy).

\section{Concomitant medications}

Current use of the following agents was not permitted: any topical ocular medications including tear substitutes and 
preserved or non-preserved glaucoma medications; use of any topical ocular or oral antimicrobial agent within the 3 days prior to the study; use of topical ocular corticosteroids or topical ocular nonsteroidal anti-inflammatories, within 3 days prior to the study.

\section{Study design}

Participants meeting all inclusion and exclusion criteria were evaluated by clinical exam prior to having ocular skin specimens collected. Warm compresses were not permitted prior to treatment with the eyelid hygiene solution.

The study schedule is shown in Table 1. Briefly, visual acuity (by ETDRS or Snellen) was assessed in the right eye. Each patient completed a symptom scale assessment for each eye. Patients rated burning/stinging, itching, foreign body sensation/irritation, redness, swelling, and crusting eyelids on a scale ranging from 0 (no symptoms) to 10 (most symptoms). The 12-question Ocular Surface Disease Index ${ }^{\odot}\left(\mathrm{OSDI}^{\odot}\right)^{18}$ was administered. Slit-lamp biomicroscopy performed in the right eye to evaluate the lid, lashes, conjunctiva, cornea, anterior chamber, and lens for the presence of active inflammation and/or active structural change and abnormalities. Study personnel obtained anterior segment/eye lid, upper and lower lids photos and a full facial photo of the patients (using a smart phone with a slit-lamp camera adapter or a digital slit lamp camera) for independent reviewer evaluation. Tear samples were collected using a diagnostic test strip in order to conduct evaluations with

Table I Study flowchart

\begin{tabular}{ll}
\hline Schedule of events & Visit I \\
& $\begin{array}{l}\text { Screening, single } \\
\text { treatment, exit }\end{array}$ \\
\hline Informed consent (IC) and assign subject number & $\mathrm{X}$ \\
General information: demographics and medical & $\mathrm{X}$ \\
and ophthalmic history & \\
Concomitant medications & $\mathrm{X}$ \\
Visual acuity OU & $\mathrm{X}$ \\
Subject symptom scale & $\mathrm{X}$ \\
Ocular Surface Disease Index ${ }^{\odot}$ (OSDI ${ }^{\odot}$ ) & $\mathrm{X}$ \\
Slit-lamp biomicroscopy OU without fluorescein & $\mathrm{X}$ \\
Inclusion/exclusion criteria & $\mathrm{X}$ \\
Anterior segment photography OU & $\mathrm{X}$ \\
InflammaDry ${ }^{\circledR}$ test & $\mathrm{X}$ \\
Ocular microbiological swab specimens OU & $\mathrm{X}$ \\
Dispense open-label HOCl cleanser & $\mathrm{X}$ \\
Observe first application of Avenova ${ }^{\circledR}$ (in-office) & $\mathrm{X}$ \\
Ocular microbiological swab specimens OU & $\mathrm{X}$ \\
Record adverse events & $\mathrm{X}$ \\
Slit-lamp biomicroscopy OU with fluorescein & $\mathrm{X}$ \\
Fluorescein tear break-up time OU & $\mathrm{X}$ \\
\hline
\end{tabular}

Abbreviations: $\mathrm{HOCl}$, hypochlorous acid; $\mathrm{OU}$, both eyes. inflammatory kits (InflammaDry ${ }^{\circledR}$ test; Rapid Pathogen Screening Inc., Sarasota, FL, USA) for each patient. Microbiological specimens were collected before and 20 minutes after application of the product.

The test product, Avenova ${ }^{\circledR}$ (NovaBay Pharmaceuticals, Inc., Emeryville, CA), is HOCl-preserved ( $0.01 \%)$ normal saline solution, $\mathrm{pH}$ 4.0. There are no other preservatives present.

Participants (or parent/guardian) received instructions on the proper method of applying the product to the ocular skin, lid, and lashes according to the package insert. Briefly, 2-3 sprays of the product were applied to a cotton round or oval and the product was applied with the eyes closed. The participants then applied the hygiene solution in the physician's office under supervision of trained site personnel. Warm compresses were not used prior to or after use of the product. Following treatment, slit lamp biomicroscopy was performed with fluorescein to grade corneal staining according to the Oxford scale. Fluorescein tear break-up time analyses were performed. Investigators graded ocular signs (lid erythema, lid swelling, lid crusting and debris on lashes, bulbar and palpebral conjunctival injection, and meibomian gland secretions [after expression]) using a 5-point scale (absent or normal $=0$; trace $=0.5$, mild $=1$; moderate $=2$; severe $=3$ ).

\section{Microbiological specimen collection, growth conditions, and bacteria quantitation}

The collection of the microbiological specimens from the surface of the skin below each lower eyelid was accomplished using a sterile minitip Nylon flocked swab with a transport tube containing $1 \mathrm{~mL}$ of Liquid Amies medium (Copan Diagnostics Inc.; catalog number 481C). Following overnight shipment of the specimens to the central microbiology lab (International Health Management Associates, Schaumburg, IL, USA), each specimen was processed to culture aerobes and anaerobes with chocolate agar, tryptic soy agar/blood agar, and Brucella agar. The identities of the samples were masked to the Microbiology lab personnel. Quantitative results of all colony types of bacteria (colony-forming unit $[\mathrm{CFU}] / \mathrm{mL}$ ) were reported after 5 days of incubation as appropriate. Species-level identification was performed on the various colony types using MALDI-TOF or 16S rRNA gene sequencing. All different colony types were stored at $-80^{\circ} \mathrm{C}$ for further characterization studies, such as minimal inhibitory concentration (MIC) susceptibility. Broth dilution end-point MICs were determined for selected antibiotics per Clinical and Laboratory Standards Institute guidance when available. 


\section{Statistics}

The CFU/mL for each unique strain of a specific bacterial species was determined at each sampling (before and after treatment with Avenova $\left.{ }^{\circledR}\right)$. All strains of a specific species were added together and the average CFU reduction was calculated. No statistical measures were predetermined as this was a descriptive study.

\section{Results}

The study included 36 participants -22 females and 14 males. The average age of the participants was 63 years (range 19-88 years). A total of 71 of the 72 ocular specimens were processed.

Table 2 shows the 31 recovered bacterial species belonging to 14 genera. Strains of the genera Staphylococcus and Corynebacterium belonged to the most numerous distinct species 10 and 6 , respectively. The table of bacterial diversity (Table 3) demonstrates that, although there were fewer species and strains after treatment, the diversity of bacterial genera and species was not appreciably different after treatment with the HOCl hygiene solution. This can also be seen in the pie charts showing the bacterial diversity before and after treatment (Figure 1).

The percentages of total bacterial isolates prior to treatment for key genera/species were $60 \%$ for Staphylococcus, $36 \%$ for $S$. epidermidis, and $22 \%$ for $P$. acnes. The change in bacterial load, in terms of both numbers of unique strains and CFUs dramatically decreased after treatment (Table 4). Treatment with $0.01 \% \mathrm{HOCl}$ hygiene solution resulted in a $99.6 \%$ reduction in the number of staphylococci CFUs

Table 2 Total bacterial species recovered from the skin below 71 eyelids

\begin{tabular}{ll}
\hline Genus & Bacterial species \\
\hline Staphylococcus & S. aureus, S. capitis, S. caprae, S. epidermidis, \\
& S. haemolyticus, S. hominis, S. lugdunensis, \\
S. pasteuri, S. simulans, S. warneri \\
Corynebacterium & C. accolens, C. bovis, C. confusum, C. macginleyi, \\
Bacillus & C. propinquum, C. tuberculostearicum \\
Enterococcus & B. circulans, B. pumilus \\
Micrococcus & E. faecalis \\
Rothia & M. luteus \\
Streptococcus & R. dentocariosa \\
Propionibacterium & S. mitis \\
Prevotella & P. acnes, P. avidum, P. granulosum \\
Enterobacter & P. oris \\
Moraxella & E. aerogenes \\
Neiserria & M. osloensis \\
Pantoea & N. flavescens \\
Pseudomonas & P. agglomerans \\
\hline & P. aeruginosa, P. oryzihabitans
\end{tabular}

Table 3 Bacterial diversity on the skin below the eyelid

\begin{tabular}{llllll}
\hline Bacterial & \multicolumn{2}{l}{ Number of species } & & \multicolumn{2}{c}{ Number of strains } \\
\cline { 2 - 3 } \cline { 5 - 6 } groups & Time $=\mathbf{0}$ & $\begin{array}{l}\text { Time }= \\
\text { 20 minutes }\end{array}$ & & Time $=\mathbf{0}$ & Time $=$ \\
\hline Gram-positive & 22 & 12 & & 20 minutes \\
Anaerobes & 4 & 2 & 39 & 35 \\
Gram-negative & 5 & 1 & 6 & I \\
\hline
\end{tabular}

at 20 minutes and a $99.5 \%$ reduction in $S$. epidermidis CFUs (Figure 2).

The susceptibility profile to selected antibiotics for the $S$. epidermidis isolates recovered before and 20 minutes after one application of the eyelid hygiene solution to the surface of the skin just below the eyelid is presented in Table 5. The percentage of isolates resistant to each antibiotic tested (and the breakpoint used to define resistance) demonstrates that the percentage of strains resistant to a given antibiotic after a single application of $\mathrm{HOCl}$-preserved hygiene solution was comparable to that observed before the use of the cleanser. Table 6 shows that the susceptibilities of S. epidermidis isolates to erythromycin and tobramycin were comparable to those observed in previous studies. ${ }^{2,12}$

A detailed genetic analysis of the strains that were recovered after treatment revealed that some of the strains were distinctly different than the strains recovered prior to treatment. These strains (not recovered at time 0 ) belonged to 12 Gram-positive species, 6 anaerobic species, and 1 Gramnegative species (Table 7). Staphylococci accounted for 44 of these strains and $70 \%$ (31) of these staphylococci strains were S. epidermidis (Table 8).

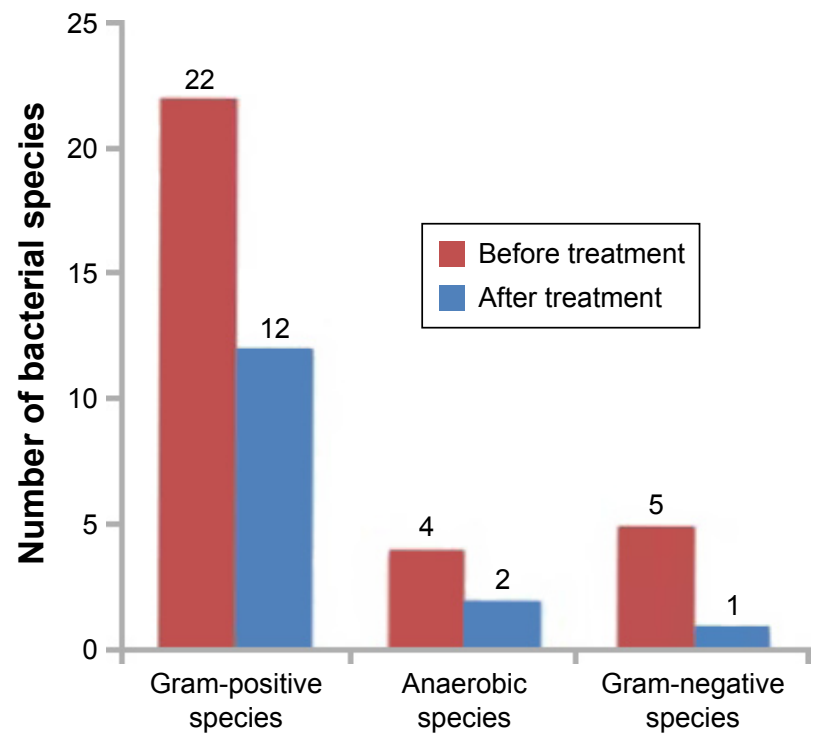

Figure I Bacterial diversity on the skin below the eyelid before treatment and 20 minutes after treatment with $0.01 \%$ hypochlorous acid hygiene solution. 
Table 4 Bacterial load of staphylococci and $P$. acnes on the skin below the eyelid

\begin{tabular}{llllll}
\hline $\begin{array}{l}\text { Bacterial } \\
\text { species }\end{array}$ & \multicolumn{2}{l}{ Number of strains } & & \multicolumn{2}{l}{ Colony-forming units } \\
\cline { 2 - 3 } \cline { 5 - 6 } & Time $=\mathbf{0}$ & $\begin{array}{l}\text { Time }= \\
\mathbf{2 0} \text { minutes }\end{array}$ & & Time $=\mathbf{0}$ & $\begin{array}{l}\text { Time }= \\
\mathbf{2 0} \text { minutes }\end{array}$ \\
\hline Staphylococci & 98 & 24 & $2,362,786$ & $10,094(0.43 \%)$ \\
S. epidermidis & 60 & 18 & & $1,830,774$ & $9,898(0.54 \%)$ \\
P. acnes* & 37 & 23 & & 12,582 & $896(7.1 \%)$ \\
\hline
\end{tabular}

Note: *Strain-level analysis was not performed

\section{Discussion}

In this study, the diversity of microbial species did not change significantly after single treatment with $0.01 \% \mathrm{HOCl}$ hygiene solution. This analysis suggests that the eyelid hygiene solution did not eliminate the resident commensal bacteria in the area of skin below the lower eyelids. A single application of the eyelid hygiene solution with $0.01 \% \mathrm{HOCl}$ provided a dramatic $99.6 \%$ decrease in the bacterial load of staphylococci. The application reduced the bacterial load of susceptible and/or resistant phenotypes to various antibiotics equally well.

The percentage of strains resistant to a given antibiotic after a single application of $\mathrm{HOCl}$-preserved hygiene solution was comparable to that observed before the application of the cleanser. This supports the notion that $\mathrm{HOCl}$ removes the susceptible strains equally well as those that are resistant to various antibiotics. Of further interest, is the

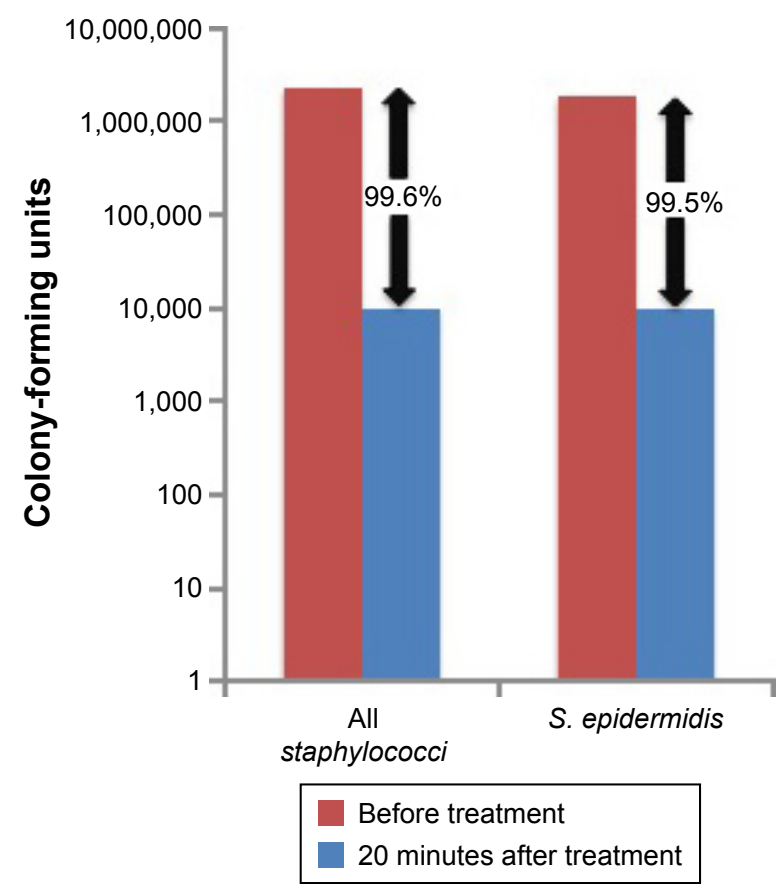

Figure 2 The CFU reduction in the staphylococci load 20 minutes following treatment with $0.01 \%$ hypochlorous acid hygiene solution.

Abbreviation: CFU, colony-forming units. fact the S. epidermidis data demonstrate similar percentages of strains susceptible to erythromycin and tobramycin was reported by Groden et al. ${ }^{12}$ The differences in susceptibility between the S. epidermidis data reported in 1984 and this report could be due to differences in breakpoints used to calculate percent susceptibility, differences in testing methodologies, and so on. It is also not easy to compare susceptibility data for all staphylococci with $S$. epidermidis data since there are some rather large differences in intrinsic susceptibility to various antibiotics among the 45 species of coagulase-negative staphylococci.

The fact that different strains were uncovered/emerged 20 minutes after an application of eyelid hygiene solution most likely reflects the effect of rubbing the skin with the applicator pad and removing the top layer of bacteria. After 20 minutes, other strains were recovered even in the same area of skin. Because of how and where the bacteria replicate on the surface of the skin, ${ }^{1}$ it is doubtful whether the surface can be really "sterilized"; however, it is clearly demonstrated that the eyelid hygiene solution preserved with $\mathrm{HOCl}$ reduces the microbial load by $>90 \%$ on the surface of the skin.

The conjunctiva and eyelids are not well characterized in terms of bacterial diversity. As with other areas of the body, diseases and other factors can affect the microbiome. Contact lens wearers have more variable and skin-like bacterial community structures, with higher abundances of Methylobacterium, Lactobacillus, Acinetobacter, and Pseudomonas and lower abundances of Haemophilus, Streptococcus, Staphylococcus, and Corynebacterium compared with non-lens wearers. ${ }^{19}$

A recent study in blepharitis patients demonstrated the percentages of the positive cultures and the number of colonies/patient were higher for blepharitis patients compared with healthy controls. ${ }^{20}$ Corynebacterium spp. were the most common microorganisms isolated from blepharitis patients (the percentages of positive cultures: $53.7 \%$ vs $18 \%$ for controls, $P<0.01$ ), and the bacterial load was $>14$ times in blepharitis patients compared with controls. Corynebacterium macginleyi was the most common corynebacterium species $(33 \%$ vs $6 \%$ positive cultures, $P<0.01)$. S. epidermidis showed $35.1 \%$ versus $16 \%(P=0.02)$ positive cultures with $11.3 \mathrm{CFU} /$ case versus $1.6 \mathrm{CFU} /$ case, respectively. $S$. aureus yielded $13 \%$ versus $0 \%(P=0.01)$ positive cultures with 24.7 CFU/case versus 0 . No significant difference was observed between blepharitis patients and controls for $P$. acnes ( $14.8 \%$ vs $14 \%$ with $4.7 \mathrm{CFU} /$ case vs $5.1 \mathrm{CFU} /$ case). The authors concluded that Corynebacterium sp., S. epidermidis, 
Table 5 Susceptibility profile of S. epidermidis to selected antibiotics

\begin{tabular}{|c|c|c|c|c|}
\hline \multirow[t]{2}{*}{ Antibiotics } & \multirow{2}{*}{$\begin{array}{l}\text { Resistance } \\
\text { breakpoints } \\
(\mu \mathrm{g} / \mathrm{mL})\end{array}$} & \multicolumn{3}{|c|}{$\%$ resistant strains } \\
\hline & & $\begin{array}{l}\text { Before } \\
\text { application }\end{array}$ & $\begin{array}{l}\text { Strains removed } \\
\text { at } 20 \text { minutes }\end{array}$ & $\begin{array}{l}\text { Strains remaining } \\
\text { at } 20 \text { minutes }\end{array}$ \\
\hline Oxacillin (methicillin) & $>2$ & $28 \%(17 / 60)$ & $29 \%(12 / 42)$ & $28 \%(5 / / 8)$ \\
\hline Penicillin & $>1$ & $45 \%(27 / 60)$ & $40 \%(17 / 42)$ & $56 \%(10 / 18)$ \\
\hline Tobramycin & $>1$ & $27 \%(16 / 60)$ & $24 \%(10 / 42)$ & $33 \%(6 / 18)$ \\
\hline Erythromycin & $>1$ & $47 \%(28 / 60)$ & $45 \%(19 / 42)$ & $50 \%(9 / 18)$ \\
\hline Clindamycin & $>1$ & $10 \%(6 / 60)$ & $10 \%(4 / 42)$ & $10 \%(2 / 18)$ \\
\hline Ciprofloxacin & $>1$ & $27 \%(16 / 60)$ & $24 \%(10 / 42)$ & $33 \%(6 / 18)$ \\
\hline Tetracycline & $>2$ & $8.3 \%(5 / 60)$ & $4.7 \%(2 / 42)$ & $17 \%(3 / 18)$ \\
\hline Trimethoprim & $>4$ & $22 \%(13 / 60)$ & $21 \%(9 / 42)$ & $22 \%(4 / 18)$ \\
\hline Sulfamethoxazole & $>64$ & $12 \%(7 / 60)$ & $9.5 \%(4 / 42)$ & $17 \%(3 / 18)$ \\
\hline
\end{tabular}

and $S$. aureus appeared to participate actively in the physiopathology of blepharitis. ${ }^{20}$

Results from the current study support this conclusion since corynebacterial and staphylococcal isolates, particularly $S$. epidermidis, were the most common bacteria recovered in blepharitis and MGD patients prior to treatment. Staphylococcal isolates also had a large contribution to the bacterial load of the skin near the lower eyelid ( $>2$ million CFUs before treatment). The quantitation of bacterial load demonstrated a $>99 \%$ reduction for staphylococci and $S$. edpidermidis CFUs after single treatment with $0.01 \% \mathrm{HOCl}$ hygiene solution. Although $P$. acnes was a frequently recovered bacterial species in this study, it had only a relatively small contribution to the bacterial load ( $<13,000$ CFUs).

The results of the current study also corroborate those from Dougherty and $\mathrm{McCulley}^{2}$ in which coagulasenegative Staphylococcus spp., P. acnes, and cornyneform bacteria were the most commonly isolated bacteria from the lids of blepharitis patients. Cultures of material expressed from the meibomian glands recovered similar organisms (including Staphylococcus spp. [such as S. epidermidis],
$P$. acnes, and coryneform bacteria). ${ }^{2}$ These bacteria were found in lower abundances following application with $0.01 \%$ $\mathrm{HOCl}$ hygiene solution.

Although some investigators have suggested that coagulase-negative Staphylococcus spp. (eg, S. epidermidis) is a pathogenic species that could play a causative role in blepharitis, ${ }^{2,12}$ other roles of this species have also been put forth. It has been hypothesized that $S$. epidermidis might have evolved to maintain a benign commensal relationship with the host, instead of causing disease. ${ }^{21}$ S. epidermidis might even play a probiotic role by competing with more severe pathogens, such as $S$. aureus, another prevalent species in patients with blepharitis. ${ }^{11}$

$\mathrm{HOCl}$ has different mechanisms from antibiotics for killing bacteria. The compound acts as an oxidant and its bacteriocidal effect is the result of lipid peroxidation or halogenation. ${ }^{15}$ If a reduction in the bacterial load occurs without the loss of commensal bacteria species, ${ }^{22}$ treatment with $\mathrm{HOCl}$ hygiene solution could be beneficial.

A perturbation of the skin microbiome can lead to a pathologic imbalance of commensal bacteria. ${ }^{22,23}$ This imbalance can trigger release of lipopolysaccharides, exotoxins, and

Table 6 Percent susceptibilities to erythromycin, tetracycline, and tobramycin

\begin{tabular}{|c|c|c|c|c|}
\hline \multirow[t]{2}{*}{ Antibiotic } & \multirow[t]{2}{*}{ Isolates (N) } & \multicolumn{3}{|c|}{ Percent susceptibilities } \\
\hline & & This study & $\begin{array}{l}\text { Groden et al's } \\
\text { study'12 }\end{array}$ & $\begin{array}{l}\text { Dougherty and } \\
\text { McCulley's study }\end{array}$ \\
\hline \multirow[t]{3}{*}{ Tetracycline } & S. epidermidis (60) & $92 \%$ & & \\
\hline & S. epidermidis (332) & & ND & \\
\hline & Staphylococci (773) & & & $67 \%$ \\
\hline \multirow[t]{3}{*}{ Erythromycin } & S. epidermidis (60) & $53 \%$ & & \\
\hline & S. epidermidis (332) & & $48 \%$ & \\
\hline & Staphylococci (773) & & & $89 \%$ \\
\hline \multirow[t]{3}{*}{ Tobramycin } & S. epidermidis (60) & $73 \%$ & & \\
\hline & S. epidermidis (332) & & $74 \%$ & \\
\hline & Staphylococci (773) & & & ND \\
\hline
\end{tabular}

Abbreviation: ND, not determined. 
Table 7 Species/strains emerging after treatment with $0.01 \%$ hypochlorous acid

\begin{tabular}{|c|c|c|c|c|c|}
\hline \multirow[t]{2}{*}{ Bacterial groups } & \multicolumn{2}{|c|}{ Bacterial species } & \multicolumn{2}{|l|}{ Strains } & \multirow{2}{*}{$\begin{array}{l}\text { Strains not } \\
\text { recovered at } \\
\text { time } 0 \\
\text { Time }=20 \text { minutes }\end{array}$} \\
\hline & Time $=0$ & Time $=\mathbf{2 0}$ minutes & Time $=0$ & Time $=\mathbf{2 0}$ minutes & \\
\hline Gram-positive & 22 & 12 & 117 & 35 & 54 \\
\hline Anaerobes & 4 & 1 & 39 & 23 & 6 \\
\hline Gram-negative & 5 & 0 & 6 & 0 & 1 \\
\hline
\end{tabular}

lipase activation. Eyelid inflammation and changes in tear lipids can ensue, which can lead to reduced tear film stability. In addition, lipase activity within the ocular surface environment can lead to saponification with further degradation of lipid layer cohesivity and exacerbation of dry eye signs and symptoms. ${ }^{24}$ It is important, therefore, that a cleanser reduces that bacterial load but does not significantly affect the diversity of resident species around the eyelids.

Previous studies have suggested that patients with eyelid abnormalities such as blepharitis are at higher risk for developing postoperative endophthalmitis. ${ }^{25}$ Miño de Kaspar et $\mathrm{al}^{26}$ found a significant increase in the incidence of multiresistant bacteria in patients with local (eg, blepharitis) and/or systemic risk factors (diabetes or skin disease) compared with healthy patients with normal eyelids.

The importance of lid hygiene before ocular surgery was highlighted in a recent study by Peral et al. ${ }^{27}$ This singlecenter prospective study evaluated the ocular microbiota of 45 consecutive patients who treated their eyes scheduled for surgery twice a day for 5 days with a regimen of heat, massage, and sterile eyelid wipes containing hyaluronic acid, capryloyl glycine, iris florentine, and centella asiatica. On treatment days 0,3 , and 5, microbiota samples were taken from the surface of the lower lid and the inferior conjunctival sac fundus of both eyes. The samples were then cultured on blood and chocolate agar plates and incubated aerobically for 48 hours at $37^{\circ} \mathrm{C}$. Prior to treatment, the most prevalent bacterial species recovered from the eyelid

Table 8 Species/strains emerging after treatment with $0.01 \%$ hypochlorous acid

\begin{tabular}{llll}
\hline $\begin{array}{l}\text { Bacterial } \\
\text { species }\end{array}$ & $\begin{array}{l}\text { Number of unique } \\
\text { strains }\end{array}$ & $\begin{array}{l}\text { Strains not } \\
\text { recovered } \\
\text { at time 0 }\end{array}$ \\
\cline { 2 - 3 } & Time $=\mathbf{0}$ & $\begin{array}{l}\text { Time }=\mathbf{2 0} \\
\text { minutes }\end{array}$ & $\begin{array}{l}\text { Time }=\mathbf{2 0} \\
\text { minutes }\end{array}$ \\
\hline Staphylococci & 98 & 24 & 44 \\
S. epidermidis & 60 & 18 & 31 \\
P. acnes* & 37 & 23 & 6 \\
\hline
\end{tabular}

Note: *Strain-level analysis was not performed. samples, from most to least prevalent, were S. epidermidis, Corynebacterium spp., Micrococcus spp., S. aureus, and Bacillus spp. On days 3 and 5 of treatment, the microbial load on the eyelids was reduced by $58 \%$ and $63 \%$, respectively, ( $P=0.0011$ compared with the nontreated eyes). The authors proposed that eyelid hygiene can be used as a complementary prophylactic approach before ocular surgery to reduce the risk of postoperative infections such as endophthalmitis. The prevalent species identified prior to treatment in the Peral et al' ${ }^{27}$ study were consistent with those of the current study in patients with blepharitis and MGD. The reductions in bacterial loads with a single $\mathrm{HOCl}$ treatment compared favorably with those seen after 3 and 5 days of a twice-a-day regimen of sterile eyelid wipes.

Skin near the lid margin should recolonize rapidly after $\mathrm{HOCl}$ treatment by isolates from surrounding skin. The data from this study support the concept that multiple treatments with $\mathrm{HOCl}$ per day are required to achieve optimal benefits. Reduction in the bacterial load can be useful for management of blepharitis, MGD, dry eye, and other forms of ocular irritation.

This study had several limitations, which affect the conclusions that can be drawn. The sample size in terms of the number of patients was relatively small and only one treatment with the $\mathrm{HOCl}$ hygiene solution was performed. The study did not have a control from which to base comparisons. Only descriptive statistics on categorical variables were performed. Finally, patient signs and symptoms after treatment were not assessed.

\section{Conclusion}

In summary, staphylococci accounted for $\sim 61 \%$ of all strains recovered from the skin under the lower eyelid. S. epidermidis strains comprised $60 \%$ of the staphylococcal strains identified. The application of pure $\mathrm{HOCl}$ hygiene solution did not significantly alter the diversity of the bacterial species recovered. Treatment with $\mathrm{HOCl}$ did not selectively remove susceptible strains of bacteria. However, the $\mathrm{HOCl}$ hygiene solution did reduce potentially clinically 
significant bacterial overpopulation by decreasing the bacterial load $>90 \%$.

\section{Acknowledgment}

The authors would like to acknowledge Julie Crider, PhD, for medical writing contributions. This study was presented at the Association for Research and Vision in Ophthalmology Meeting, May 2, 2016, in Seattle, WA, USA. The abstract is available at https://ep70.eventpilot.us/web/page.php?na $\underline{\mathrm{v}=\text { false\&page }=\text { IntHtml\&project }=\text { ARVO16\&id=2449758. }}$. This study was sponsored by Novabay Pharmaceuticals, Inc., Emeryville, CA, USA.

\section{Disclosure}

David W Stroman, Keri Mintun, and Kathryn Najafi-Tagol are employees of NovaBay Pharmaceuticals. Arthur B Epstein and James D Branch are consultants for NovaBay Pharmaceuticals. Crystal M Brimer and Chirag R Patel have no conflicts to disclose in this work.

\section{References}

1. Grice EA, Segre JA. The skin microbiome. Nat Rev Microbiol. 2011; 9(4):244-253.

2. Dougherty JM, McCulley JP. Comparative bacteriology of chronic blepharitis. Br J Ophthalmol. 1984;68(8):524-528.

3. American Academy of Ophthalmology. Cornea/External Disease Panel. Preferred Practice Pattern ${ }^{\circledR}$ Guidelines. Blepharitis. San Francisco: American Academy of Ophthalmology; 2013. Available from: http:// www.aao.org/ppp. Accessed January 20, 2017.

4. Nichols KK, Foulks GN, Bron AJ, et al. The international workshop on meibomian gland dysfunction: executive summary. Invest Ophthalmol Vis Sci. 2011;52(4):1922-1929.

5. Nelson JD, Shimazaki J, Benitez-del-Castillo JM, et al. The international workshop on meibomian gland dysfunction: report of the definition and classification subcommittee. Invest Ophthalmol Vis Sci. 2011;52(4): 1930-1937.

6. Baudouin C, Messmer EM, Aragona P, et al. Revisiting the vicious circle of dry eye disease: a focus on the pathophysiology of meibomian gland dysfunction. Br J Ophthalmol. 2016;100(3):300-306.

7. Lemp MA, Crews LA, Bron AJ, Foulks GN, Sullivan BD. Distribution of aqueous-deficient and evaporative dry eye in a clinic-based patient cohort: a retrospective study. Cornea. 2012;31(5):472-478.

8. Wick JY. Treating blepharitis: annoying condition for patients, vocabulary builder for pharmacists. Pharmacy Times. February 20, 2012. Available from: http://www.pharmacytimes.com/publications/ issue/2012/february2012/treating-blepharitis-annoying-condition-forpatients-vocabulary-builder-for-pharmacists. Accessed June 15, 2016.
9. Schaumberg DA, Sullivan DA, Buring JE, Dana MR. Prevalence of dry eye syndrome among US women. Am J Ophthalmol. 2003;136(2): 318-326.

10. Lee SH, Oh DH, Jung JY, Kim JC, Jeon CO. Comparative ocular microbial communities in humans with and without blepharitis. Invest Ophthalmol Vis Sci. 2012;53(9):5585-5593.

11. Lina G, Boutite F, Tristan A, Bes M, Etienne J, Vandenesch F. Bacterial competition for human nasal cavity colonization: role of Staphylococcal agr alleles. Appl Environ Microbiol. 2003;69(1):18-23.

12. Groden LR, Murphy B, Rodnite J, Genvert GI. Lid flora in blepharitis. Cornea. 1991;10(1):50-53.

13. Suzuki T, Sano Y, Sasaki O, Kinoshita S. Ocular surface inflammation induced by Propionibacterium acnes. Cornea. 2002;21(8):812-817.

14. Hurst JK. What really happens in the neutrophil phagosome? Free Radic Biol Med. 2012;53(3):508-520.

15. Kumar V, Abbas AK, Fausto N. Acute and chronic inflammation. Robbins and Cotran Pathologic Basis of Disease. 7th ed. Philadelphia: Elsevier; 2005:29-73.

16. Wang L, Bassiri M, Najafi R, et al. Hypochlorous acid as a potential wound care agent: part I. Stabilized hypochlorous acid: a component of the inorganic armamentarium of innate immunity. J Burns Wounds. 2007;6:e5.

17. Avenova ${ }^{\circledR}$ with Neutrox ${ }^{\circledR}$ [package insert]. Emeryville, CA: NovaBay Pharmaceuticals, Inc.; 2014.

18. Schiffman RM, Christianson MD, Jacobsen G, Hirsch JD, Reis BL. Reliability and validity of the Ocular Surface Disease Index. Arch Ophthalmol. 2000;118(5):615-621.

19. Shin H, Price K, Albert L, Dodick J, Park L, Dominguez-Bello MG. Changes in the eye microbiota associated with contact lens wearing. mBio. 2016;7(2):e00198.

20. Bezza Benkaouha I, Le Brun C, Pisella PJ, Chandenier J, Lanotte P. [Bacterial flora in blepharitis]. J Fr Ophtalmol. 2015;38(8):723-728. French [with English abstract].

21. Otto M. Staphylococcus epidermidis - the 'accidental' pathogen. Nat Rev Microbiol. 2009;7(8):555-567.

22. Flanagan JL, Khandekar N, Zhu H, et al. Glycerol monolaurate inhibits lipase production by clinical ocular isolates without affecting bacterial cell viability. Invest Ophthalmol Vis Sci. 2016;57(2):544-550.

23. Veldman P, Colby K. Current evidence for topical azithromycin $1 \%$ ophthalmic solution in the treatment of blepharitis and blepharitisassociated ocular dryness. Int Ophthalmol Clin. 2011;51(4):43-52.

24. Foulks GN, Borchman D, Yappert M, Kim SH, McKay JW. Topical azithromycin therapy for meibomian gland dysfunction: clinical response and lipid alterations. Cornea. 2010;29(7):781-788.

25. Scott IU, Flynn HW Jr, Feuer W. Endophthalmitis after secondary intraocular lens implantation. A case-report study. Ophthalmology. 1995; 102(12):1925-1931.

26. Miño de Kaspar H, Shriver EM, Nguyen EV, et al. Risk factors for antibiotic-resistant conjunctival bacterial flora in patients undergoing intraocular surgery. Graefes Arch Clin Exp Ophthalmol. 2003;241(9): 730-733.

27. Peral A, Alonso J, García-García C, Niño-Rueda C, Calvo Del Bosque P. Importance of lid hygiene before ocular surgery: qualitative and quantitative analysis of eyelid and conjunctiva microbiota. Eye Contact Lens. 2016;42(6):366-370.
Clinical Ophthalmology

\section{Publish your work in this journal}

Clinical Ophthalmology is an international, peer-reviewed journal covering all subspecialties within ophthalmology. Key topics include: Optometry; Visual science; Pharmacology and drug therapy in eye diseases; Basic Sciences; Primary and Secondary eye care; Patient Safety and Quality of Care Improvements. This journal is indexed on Submit your manuscript here: http://www.dovepress.com/clinical-ophthalmology-journal

\section{Dovepress}

PubMed Central and CAS, and is the official journal of The Society of Clinical Ophthalmology (SCO). The manuscript management system is completely online and includes a very quick and fair peer-review system, which is all easy to use. Visit http://www.dovepress.com/ testimonials.php to read real quotes from published authors. 